Science, Technology and Development 34 (1): 41-45, 2015

ISSN 0254-6418 / DOI: 10.3923/std.2015.41.45

(C) 2015 Pakistan Council for Science and Technology

\title{
Prevalence and Molecular Detection of Giardia in Different Sources of Water
}

\author{
${ }^{1}$ Lubna Hassan, ${ }^{2}$ Fahim Ullah and ${ }^{2}$ Mansoor Khan Khattak \\ ${ }^{1}$ Department of Zoology, Kohat University of Science and Technology (KUST), \\ 26000, Khyber Pukhtunkhwa, Pakistan \\ ${ }^{2}$ Department of Agricultural Mechanization, The University of Agriculture Peshawar, \\ 25000, Khyber Pukhtunkhwa, Pakistan
}

\begin{abstract}
The study was conducted to know the prevalence of Giardia in water in District Karak, Khyber Pukhtunkhwa, Pakistan. The collected water sample from different villages of District Karak was tested in the lab of the Department of Zoology in Kohat University of Science and Technology. Giardia is an intestinal protozoan parasite and a major cause of diarrheal disease in human worldwide. PCR (Polymerase Chain Reaction) method was used to detect the prevalence of Giardia in tube well, bore, drainage and taper water of District Karak, Khyber Pukhtunkhwa, Pakistan. The total of 65 water samples were collected amongst. From the result the prevalence of Giardia in tube well, drainage and bore water were found 10.76, 1.53 and 1.53\%, respectively while in the sample of tape water there will be no prevalence of Giardia was detected. From the result it was concluded that a proper treatment of water for human consumptions is required.
\end{abstract}

Key words: PCR, Giardia, water source

\section{INTRODUCTION}

Giardia camphylobacter, Cryptosporidium salmonella and Escherichia coli have been the most commonly identified zoonotic agents of waterborne disease outbreak from contaminated drinking water throughout the world (Craun et al., 2004). Giardia is a flagellated, binucleated protozoan as shown in Fig. 1, discovered by Van leeuwenhoek in 1681. Giardia spp. was parasites of mammals and other animals, including reptiles and birds. It has a characteristic morphology, the vegetative trophozoite ( $15 \mathrm{~mm}$ in length), teardrop shaped two interiorly placed nuclei of equal size (Yu et al., 2002) and having four pairs of flagella (one anterior pair, two posterior pairs) and a caudal pair that emerges posterity from the disc (Elmendorf et al., 2003). The acquirement of Giardia occurs most commonly through ingestion of the cyst $(10-12 \mathrm{~mm})$ in contaminated water, but person to person spread is common, particularly in

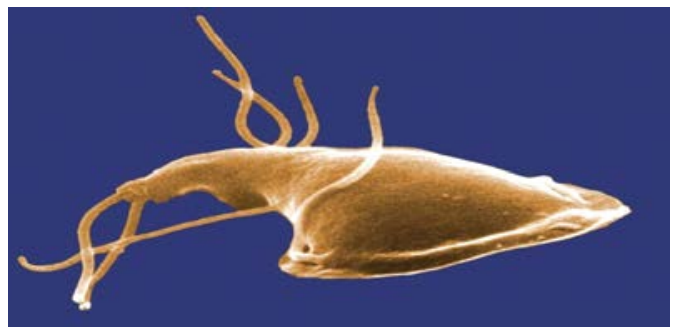

Fig. 1: Dorsal (upper) surface of a Giardia Protozoan settings of proof focal-oral hygiene. Filth flies can carry potentially viable Giardia Lamblia cyst on their exoskeleton (Graczyk et al., 2003).

The zoonotic transmissions are any infective disease that can be transmitted from animals, both wild and domestic to humans or from human to non-human animals of the 1415 pathogens known to affect humans $61 \%$ are zoonotic. Zoonotic pathogens comprise $75 \%$ of the emerging infection disease in humans (Bolin et al., 2004). Many of these emerging zoonotic are transmitted indirectly through food, water or environmental contamination. Evidence suggest that zoonotic water borne pathogens will continue to be recognized as an increasing public health concern world wide because of changing pattern in water use, climatic change, severe weather events, increasingly concentrated livestock operation and international trade in animal product (Taylor et al., 2001).

Giardia is an intestinal protozoan parasite and a chief cause of diarrheal disease in humans world wide (Berkman et al., 2002). Possible symptoms of infection include mal absorption, loose or watery stools, dehydration and abdominal cramping. The symptoms of a Giardia infection are a suite of gastrointestinal unpleasantries, same of which have been described as "explosive" and "violent" (Amar et al., 2002). Giardia is frequently found in water sources particularly those human and animal contamination is likely. Humans or animals become infected when they ingest cysts. Trophozoite, the feeding stages emerge from these cysts

Corresponding Author: Fahim Ullah, Department of Agricultural Mechanization, The University of Agriculture Peshawar, 25000, Khyber Pukhtunkhwa, Pakistan 
in the digestive tract and these stages can asexually divide (Appelbee et al., 2003).

Giardiasis spread in communities where water supplies become contaminated with raw sewage or by the ingestion of foods contaminated with fecal material containing cyst and the infectivity dose may be as low as 10 cysts. It can be contracted by drinking water from lakes or streams where water-dwelling animals such as beavers and muskrats, or domestic animals such as sheep, have caused contamination (Huang and White, 2006). The most common symptoms of Giardiasis are diarrhea, abdominal pain, bloating, flatulence and weight loss resulting from mal absorption (Chaudhry et al., 2004).

The diagnosis of Giardiasis has been classically on detection of cyst or trophozoite in stool and duodenal aspirating specimens by direct microscopic examination and duodenal endoscopic biopsy specimen by histologically. Recently proven, Enzyme linked immune sorbent assay methods for the detection of Giardia (Ali and Hill, 2003).

Water born flagellated parasite Giardia lamblia continuous to be most frequent protozoan agent of intestinal disease world-wide, causing an estimated $2.8 \times 10^{6}$ cases per annum (Ali and Hill, 2003). Giardia lamblia was the most commonly encountered parasite with a prevalence of $24.2 \%$ in Punjab. Prevalence of Giardia lamblia is $11.8 \%$ in Muzaffarabad city (Chaudhry et al., 2004). A total number of 3000 stool samples were collected from different laboratories of Sakkur, Sindh during the period of June 2005 to May 2007. Total 1050 (35\%) cases were found with intestinal pathogenic parasite in their stools. The most common parasite was Giardia lamblia found in 380 (36.19\%) cases (Shaikh et al., 2009). Prospective observational study of 239 children with recurrent abdominal pain was conducted at Department of Pediatrics, Postgraduate Medical Institute, Hyaytabad Medical Complex, Peshawar, from November 2004 to July 2006. Seventy-four (30.96\%) children were positive for Giardiasis (Younas et al., 2008). The present studies is designated with the objectives of the molecular detection of Giardia in different water sources of District Karak, Khyber Pukhtunkhwa, Pakistan and compare the water sources of contamination with drainage water.

\section{Taxonomy and classification of G. lamblia:}

- Kingdom: Protista Subkingdom: Protozoa

- Phylum: Sarcomastia Subphylum: Mastigophora

- Class: Zommastigophora Order: Diplomonadida

- Family: Hexamitidae Genus: Giardia

- Species: Lamblia (Sulaiman et al., 2003)

\section{MATERIALS AND METHODS}

Sample selection: Karak is a district of the Khyber Pukhtunkhwa, Pakistan. Sixty five sample of water were collected from different water sources of different villages. The different water sources include tap water, tube well (300 ft depth), bore water tube well (150 ft depth) and drainage water. The quantity of water sample was $1.5 \mathrm{~L}$. The predominant language is Pashto, which is spoken by all the population.

Water filtration and processing: A total of 65 water samples were randomly collected in a sterilized and clean bottle having capacity of $1 \mathrm{~L}$ directly from the water sources in Karak from different sources like (tube well, bore, drainage and taper water). The sampling was continued in summer, winter, autumn and spring March, 2012 to March, 2013. Samples were labeled with date of collection, site and nature and transported to laboratory of Zoology for further process. Samples were filtered through watt man filter paper and the material was collected from the filter paper according to the instruction. All samples were filtered at recommended flow rates and transferred into a centrifuge tube at $6000 \mathrm{rpm}$ for $15 \mathrm{~min}$. The purpose of centrifugation is to separate particles according to their density. Those having high molecular weight were settling down at the bottom and those having low molecular weight were settled above according to their density. Two layer from supernatant and pellet. The supernatant were discarded and pellet was poured into the eppendorf tube. Again those samples were run in micro centrifuge machine at $14000 \mathrm{rpm}$ for $8 \mathrm{~min}$.

DNA extraction and lyses: The DNA was extracted by DNA zole (Trizol USA) method with minor modification with the following steps. from $124 \mu \mathrm{L}$ the sample was taken and added with $250 \mu \mathrm{L}$ DNA zole. Then the mixture was mixed properly through vortex and incubated at room temperature for $5 \mathrm{~min}$.

DNA precipitation: The $125 \mu \mathrm{L}$ of iso-propanol was added to the mixture and centrifuged at $7000 \mathrm{rpm}$ for $10 \mathrm{~min}$. After centrifugation the supernatant was removed and add 125 DNA zole was added to the DNA pellet and centrifuged at $7000 \mathrm{rpm}$ for $5 \mathrm{~min}$.

DNA wash and hydration: Tow hundred microliter of $70 \%$ ethanol was added to the pellet after discarding the supernatant and centrifuge at $7000 \mathrm{rpm}$ for $5 \mathrm{~min}$. Discard the supernatant. The DNA wash step was repeated and the tubes were stored vertically to dry for $10 \mathrm{~min}$. Forty microliter of distilled water was added to the pallet and incubated at $55^{\circ} \mathrm{C}$ for $10 \mathrm{~min}$ in hotplates and were kept at $-40^{\circ} \mathrm{C}$ till use.

DNA amplification (PCR): Polymerase chain reaction reaction was carried out in a thermal cycler 
Sci. Technol. Dev., 34 (1): 41-45, 2015

Table 1: PCR cycle setup for Giardia

\begin{tabular}{llccl}
\hline Stage & Cycle & Step & Temperature $\left({ }^{\circ} \mathrm{C}\right)$ & \multicolumn{1}{c}{ Time } \\
\hline 1 & 1 & 1 & 94 & $5: 00 \mathrm{~min}$ \\
2 & 35 & 1 & 94 & $30 \mathrm{sec}$ \\
& & 2 & 57 & $30 \mathrm{sec}$ \\
& & 3 & 72 & $45 \mathrm{sec}$ \\
3 & 1 & 1 & 72 & $7: 00 \mathrm{~min}$ \\
& & 2 & 4 & Hold \\
\hline
\end{tabular}

(Nyx Technich USA) with Taq DNA polymerase (Ferments USA). The conditions for PCR cycle were given in Table 1. The amplification was performed with. Five microliter of extracted DNA by using $10 \mathrm{PM}$ of forward (5-AGGGCTCCGGCATAACTTTCC-3') and reverse (5'-GTATCTGTGACCCGTCCGAG-3') primers. The reaction mixture for a single reaction was consisted of following terms:

- $\quad$ Taq Buffer $2.1 \mu \mathrm{L}$

- $\operatorname{MgCl}_{2}(25 \mathrm{mM}) 2.4 \mu \mathrm{L}$

- dNTPs $(500 \mu \mathrm{M}) 1.0 \mu \mathrm{L}$

- $\quad$ Forward Primer $(10 \mathrm{Pm}) 1.0 \mu \mathrm{L}$

- $\quad$ Reverse Primer (10 Pm) $1.0 \mu \mathrm{L}$

- $\quad$ Dh2o $7.2 \mu \mathrm{L}$

- $\quad$ Taq, DNA Polymerase $\left(5 \mathrm{U}_{\mu} \mathrm{L}^{-1}\right) 5.0 \mu \mathrm{L}$

- $\quad$ Extracted DNA $5.0 \mu \mathrm{L}$

Gel electrophoresis: Ten microliter of PCR product was mixed with $2 \mu \mathrm{L}$ DNA loading dye and loaded in agarose gel which was prepared by dissolving $2 \mathrm{~g}$ of agarose in $100 \mathrm{~mL}$ of $0.5 \times$ TBE buffer in reaction bottle and boiled it for $2.5 \mathrm{~min}$ in microwave oven. The solution was cooled down to about $50^{\circ} \mathrm{C}$ at room temperature or water bath. Then $5 \mu \mathrm{L}$ ethidium bromides $\left(1 \mu \mathrm{g} \mathrm{L}^{-1}\right)$ was added per $100 \mathrm{~mL}$ gel solution and then poured into the gel rack. The comb was set at one side of the gel, about $5-10 \mathrm{~mm}$ from the end of the gel fixed. When the gel cooled down and become solid, the comb was remove carefully.

The holes that remain in the gel were the wells or the slots. Gel rack was placed in gel tank containing $1000 \mathrm{~mL}$ TBE buffer. Then $12 \mu \mathrm{L}$ of each sample was loaded in the wells and $12 \mu \mathrm{L}$ of DNA ladder (50 bp). The gel was run for $25 \mathrm{~min}$ at voltage of 120 volts and 500 ampere current. Gel was then examined by UV transilluminator and get documentation for picture. The specific DNA amplified product of each sample was determined by identifying the 163-bp bands for Giardia comparing with 50-bp DNA ladder (Ferment’s Germany) used as size marker.

Prevalence rate: The prevalence rate was determined by the following formula (Ayaz et al., 2011). Prevalence Rate $=($ No of parasite detected in water sample/Total no. of water samples examined) $\times 100$.
Table 2: Prevalence of Giardia in different sources of water

\begin{tabular}{|c|c|c|c|}
\hline Sources & Total & Positive & Percentage \\
\hline Tube well & 29 & 7 & 10.76 \\
\hline Bore water & 24 & 1 & 1.53 \\
\hline Drainage water & 7 & 1 & 1.53 \\
\hline Areas & Total & Positive & Percentage \\
\hline Painda Khel & 6 & 1 & 16.66 \\
\hline Atti Khel & 3 & 2 & 66.66 \\
\hline Khojaki Kala & 17 & 3 & 17.64 \\
\hline Khaider Khel & 27 & 2 & 7.40 \\
\hline Ghulam Khel & 12 & 2 & 16.66 \\
\hline
\end{tabular}

Table 4: No of water sources, positive for Giardia in Karak

\begin{tabular}{|c|c|c|c|c|}
\hline \multirow[b]{2}{*}{ Localities } & \multicolumn{4}{|c|}{ Sources } \\
\hline & $\begin{array}{l}\text { Tube } \\
\text { well }\end{array}$ & $\begin{array}{l}\text { Bore } \\
\text { water }\end{array}$ & $\begin{array}{l}\text { Drainage } \\
\text { water }\end{array}$ & Tape water \\
\hline Ghulam Khel (12) & 2 & - & - & - \\
\hline Khaider Khel (27) & 1 & - & 1 & - \\
\hline Khojaki Kala (17) & 2 & 1 & - & - \\
\hline Atti Khel (3) & 2 & - & - & - \\
\hline Painda Khel (6) & 1 & - & - & - \\
\hline
\end{tabular}

\section{RESULTS}

Total 65 water samples were collected from different localities of Karak, Khyber Pukhtunkhwa, Pakistan from different sources like tape water, tube well (300 ft depth), bore (150 ft depth) and drainage water and then these were examined through PCR. Over all prevalence of parasite was 10/65 (15.38\%). In which prevalence in tube well, bore and drainage water was 7/65 (10.76\%), 1/65 $(1.53 \%)$ and $1 / 65(1.53 \%)$ respectively showed in Table 2. The result showed that tube well water was more contaminated with Giardia than other sources of water.

Locality wise Giardia Prevalence: The sample were collected from different localities of District Karak, Khyber Pukhtunkhwa, Pakistan (Khojaki Kala, Ghulam Khel, Khaider, Khel, Painda Khel and Atti Khel) in which 1 sample out of 6 positive for Giardia in Painda Khel, 2 samples out of 3 in Atti Khel, 3 samples out of 17 in Khojaki Kala, 2 out of 27 in Khaider Khel and 2 out of 12 in Ghulam Khel as shown in Table 3.

Total water samples collected from different sources (Tube well, bore, drainage and tape water) of Ghulam Khel were 12 in which 2 samples of tube well were positive for Giardia. Twenty seven samples from Khaider Khel in which 1 of tube well and 1 of drainage were positive, 17 from Khojaki kala in which 1 of bore and 2 of tube well were positive, 3 from Atti Khel in which 2 positive of tube well and 6 from Painda Khel in which 1 positive of tube well as shown in Table 4.

\section{DISCUSSION}

The present study revealed that Giardia species were widely disturbed in water sources in Karak, Khyber Pukhtunkhwa, Pakistan. A total of 65 samples were 
examined, among which 5 were of tape water, 29 of tube well (300 ft depth), 24 of bore water (150 ft depth) and 7 were of drainage water. The overall prevalence of parasite was $15.38 \%(10 / 65)$, in which prevalence in tube well water 10.76\% (7/65), in drainage water 1.53\% (1/65) and in bore water (tube well $150 \mathrm{ft}$ depth) 1.53\% (1/65). Result of this study revealed that prevalence of parasite was greater in tube well water than in other sources.

The prevalence varies between 2 and $5 \%$ in industrialized countries and may exceed $30 \%$ in developing countries (Eligio-Garcia et al., 2005). In 1988 the World Health Organization (WHO) estimated that around 280 million people are annually infected with Giardia spp in Asia, Africa and Latin America (Ponce-Macotela et al., 2005). The higher proportion of positive samples of Giardia was found in raw storage (72.6\%) followed by raw (20.9\%) and treated (18.2\%) drinking water. water samples from 53 out of the 72 municipalities sampled contained Giardia cysts at least once (Wallis et al., 1996). In contrast result of studies conducted in Karak have marked differences as out of 65 water samples only 10 were positive for Giardia. The study reflected that the prevalence of parasite was greater in tube well water than in other sources of water. The presence of parasite more in tube well water was due to poor water supply system contamination of water supplies can also result agricultural runoff and leaking septic system (Widmer et al., 2002). The variation in the result was due to the different environmental condition of the area and the skilled man power.

\section{CONCLUSION}

From the study it was concluded that prevalence of Giardia parasite in tube well water was more than other sources of water (tube well, tape, bore and drainage water). There are possibilities that some of the pipes and connection systems may be damaged (cracks or leaked) and due to which contamination from surface may occur. It is suggested that a large scale study is required to explore the possibilities of zoonotic parasite in the water sources of Karak, Khyber Pukhtunkhwa and it is recommended that water should be treated before consumption.

\section{REFERENCES}

Ali, S.A. and D.R. Hill, 2003. Giardia intestinalis. Curr. Opin. Infect. Dis., 16: 453-460.

Amar, C.F.L., P.H. Dear, S. Pedraza-Diaz, N. Looker, E. Linnane and J. McLauchlin, 2002. Sensitive PCR-restriction fragment length polymorphism assay for detection and genotyping of Giardia duodenalis in human feces. Clin. Microbiol. J., 40: 446-452.
Appelbee, A.J., L.M. Frederick, T.L. Heitman and M.E. Olson, 2003. Prevalence and genotyping of Giardia duodenalis from beef calves in Alberta, Canada. Vet. Parasitol., 25: 289-294.

Ayaz, S., S. Khan, S.N. Khan, F. Bibi, S. Shamas and M. Akhtar, 2011. Prevalence of zoonotic parasites in drinking water of three districts of Khyber Pakhtunkhwa province, Pakistan. Pak. J. Life Soc. Sci., 9: 67-69.

Berkman, D.S., A.G. Lescano, R.H. Gilman, S.L. Lopez and M.M. Black, 2002. Effects of stunting, diarrhoeal disease and parasitic infection during infancy on cognition in late childhood: A follow-up study. Lancet, 359: 564-571.

Bolin, C., C. Brown and J. Rose, 2004. Emerging Zoonotic Diseases and Water. In: Waterborne Zoonoses: Identification, Causes and Control, Cotruvo, J., A. Dufour, G. Rees, J. Bartram, R. Carr, D.O. Cliver and G.F. Craun (Eds.). World Health Organization, Rome, Italy, ISBN-13: 978-9241562737, pp: 19-26.

Chaudhry, Z.H., M. Afzal and A.M. Malik, 2004. Epidemiological factors affecting prevalence of intestinal parasites in children of Muzaffarabad district. Pak. J. Zool., 36: 267-271.

Craun, G.F., R.L. Calderon and M.F. Craun, 2004. Waterborne Outbreaks Caused by Zoonotic Pathogens in the USA. In: Waterborne Zoonoses: Identification, Causes and Control, Cotruvo, J.A. (Ed.). IWA Publishing, London, UK., ISBN-13: 9781843390589, pp: 120-135.

Eligio-Garcia, L., A. Cortes-Campos and E. Jimenez-Cardoso, 2005. Genotype of Giardia intestinalis isolates from children and dogs and its relationship to host origin. Parasitol. Res., 97: 1-6.

Elmendorf, H.G., S.C. Dawson and J.M. McCaffery, 2003. The cytoskeleton of Giardia lamblia. Int. J. Parasitol., 33: 3-28.

Graczyk, T.K., B.H. Grimes and R. Knight, A.J. da Silva, N.J. Pieniazek and D.A. Veal, 2003. Detection of Cryptosporidium parvum and Giardia lamblia carried by synanthropic flies by combined fluorescent in situ hybridization and a monoclonal antibody. Am. J. Trop. Med. Hyg., 68: 228-232.

Huang, D.B. and A.C. White, 2006. An updated review on Cryptosporidium and Giardia. Gastroenterol. Clin. North Am., 35: 291-314.

Ponce-Macotela, M., G.E. Peralta-Abarca and M.N. Martinez-Gordillo, 2005. Giardia intestinalis and other zoonotic parasites: prevalence in adult dogs from the Southern part of Mexico City. Vet. Parasitol, 131: 1-4. 
Shaikh, S.G., R. Begum, A. Hussain and R. Shaikh, 2009. Prevalence of intestinal protozoan and Helminth parasites in Sukkur, Sindh. Sci. Ser., 41: 53-58.

Sulaiman, I.M., R. Fayer, C. Bern, R.H. Gilman and J.M. Trout et al., 2003. Triosephosphate isomerase gene characterization and potential zoonotic transmission of Giardia duodenalis. Emerg. Infect. Dis. J., 9: 1444-1452.

Taylor, L.H., S.M. Latham and M.E.J. Woolhouse, 2001. Risk factors for human disease emergence. Philos. Trans. R. Soc. London B: Biol. Sci., 356: 983-989.

Wallis, P.M., S.J. Erlandsen, I.J.I. Renton, M.E. Olson, W.J. Robertson and H. van Keulen, 1996. Prevalence of Giardia cysts and Cryptosporidium oocysts and characterization of Giardia spp. Isolated from drinking water in Canada. Applied Environ. Microbiol., 62: 2789-2797.
Widmer, G., T. Clancy, H.D. Ward, D. Miller, G.M. Batzer, C.B. Pearson and Z. Bukhari, 2002. Structural and biochemical alterations in Giardia lamblia cysts exposed to ozone. J. Parasitol., 88: 1100-1106.

Younas, M., S. Shah and A. Talaat, 2008. Frequency of Giardia lamblia infection in children with recurrent abdominal pain. J. Pak. Med. Assoc., 58: 171-174.

Yu, L.Z., C.W. Birky and R.D. Adam, 2002. The two nuclei of Giardia each have complete copies of the genome and are partitioned equationally at cytokinesis. Eukaryote Cell, 1: 191-199. 